\section{二,三の $\mathrm{SBR}$ 粘着剂}

黄麖雲*

\section{1. 緒言}

素練り直後の天然ゴム, あるいは天然ゴム配合物はわ ずかな圧力により二つのゴム片は互に粘着して, 接着に 近い引張強さを示す。もちろん素練り直後でなくとも, かなり長時間放置においてもな拈粘着性をもつ。

たとえ粘着性が低下してあっても, 天然ゴムは表面を わずかな溶㓮、たとえば, ゴム揮発油, ベンゼン, トル

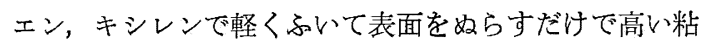
着性を復活し，加工に役立つ。しかるに SBR はかかる 粘着力が非常に乏しい。ゴムタイヤ工業のように,ゴム 製品の積層品に拉ける粘着性の欠乏は工業的に加工の重 要な問題である。

一般にゴム工業で粘着物質として天然ゴムに 配合し, 広くヨ゙ムシートおよびセメントに用いられている物質に ロジン, ロジンエステル, ピッチ, パインタール, クマ ロンーインデン樹脂などがある。これらの物質とその配 合物はわずかに SBR に粘着性を与えるのみであると伝 えられている。これらは本質的に SBR に対してビルリ ングタックを演ずるものではない。これらの結論から本 質的な粘着剤の研究が各方面で研究されるにいたった。

ドイッで合成ゴム(ブナS) を加工する際, 適当な熱処 理をすると接着力が増大するといわれている。Firestone Tire \& Rubber 社の Smith ら ${ }^{1)}$ の研究によれば, SBR をエアーボンブ, あるいは怰で加熱処理したが, わずかに 粘着性が上昇しただけで, 基本配本では彼らのいらビル リングタックをもつとはいえないといっている。また粘 着性を賦与するために種々の変性”も考慮されている が, かえってゴムタイヤとしての望をしい性質が遠ざか ってゆくようである。

\section{2. 粘着性とは}

粘着性 (Tackiness, Stickiness) を定義することは非 常にむずかしい。なんとなれば，粘着という現象はあま りわかられていないばかりでなく, 物理的な性質も十分 解明されていない。一般に粘着性は種々な因子，たとえ び接着, 疑集, 表面張力, 粘度, 接触温度などによって物

* 日本虑斯化学株式会社大阪研究所
理的にわかっている諸性質の組合せか ら先に考えるのが妥当と考える。

ところが，実際，われわれが日ごろ 粘着テープとして親しまれているテー プの粘着性とゴム工業でいう粘着性と いらものは用途からみていたって混同 しやすい。たとえば, 自動車の車体の 外装に赤や青できれいな線が描かれて いる。この線は幅の一定した粘着テー プを張りつけ，その上にスプレー塗装 をしたのち, このテープをめくるとテープの幅に下地の 色があざやかに現われる。しかしこのときに粘着テープ に接着性があるとすると, すなわち粘着剤が車体に残る ようなことがあれば，その上にさらに塗装を行ならよう な場合があればむらができて大きい支障をきたす。筆者 はこれに苦い経験をもっている。しかし，ゴム加工工業 でさす粘着はほとんどの場合接着を前提として考える。 したがって接着でいう初期粘着と単なる粘着とでは用途 の上で基本的に異なった考え方をもつことになる。

本稿は, 主としてゴム工業でさす接着を前提とする初 期粘着性について考える。二つのゴム片がわずかの圧力 によって互にねばついて離れないようになる。この力は 粘着力といい,このような性質を自己粘着 (Autohesion) という。Scott ${ }^{3)}$ はゴムの自己粘着性に対して,

（1）二つの粘いゴム表面を接触せしめたとき，二つの 表面が完全にかつ深く接触している場合

（2）表面層の相互拡散によって分子が非化学的にから み合って裂け目を生じない場合

のような物理的状態にあるものをさしている。（1）の場 合は良き接着への前提として働き, 全表面にわたってよ く接触している状態をさし，二つのゴムが触れ合ったと きに極在的な流れによって同じ平均した高さを示し，し かもその流れはわずかなストレスによって容易に生ずる ときに起る。（2）の場合は（1）の流れと異なり,表面層 の拡散と疑集力が大きく働く場合に高い值を示す。した がって分子の流れやすい性質とか, あるいは表面層の拡 散によるからみ合いは, 分子量が小さい方が良いことは いらまでもない。またあまり分子量が低すぎると分子の からみ合いがなくなるので, 適当な分子量が必要になっ てくるわけである。箕浦氏4)によれば 100 10,000 ポ アズぐらいの粘度が適当と述べている。

ここでゴム分子の流れ，拡散を促進するために，適当 な軟化剤の添加するか，あるいは温度を高めて結晶性を 低下さすか，または素練りによって分子量低下さすとか によって種々試みられている。

\section{3. 粘着剂としてのコレシン}

SBR が市販されてから, 英米で多くの研究者が SBR 
の粘着性を高めるためいろいろの粘着剤が研究さたてい る。極端に粘い物質の添加，たとえばポリビニルェーテ ルを加えても所期の効果を与えない。ロジンを添加する と確かに粘着性は高くなったが，SBR 自体に対するの ではなく他の物質に対するものである。この他, パイン タール, ジペンテン, コールタール軟化剂, 石油副産物, ク マロンインデンなどが試みられているが，本質的に天然 ゴムに相当する粘着性を与えるには至らず，その改良さ れた本質はただ，はり合わせの際に二つの接触面積を大 きくしているのみである。実用上ドィッで発明さたれコ レシンが SBR に対して自己粘着性を天然ゴムに近づけ たと英米の SBR の粘着剤研究者がいっている。

コレシンは第 2 次大戦中ドイッのレッペ博士がアセチ

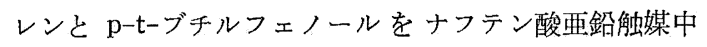
で縮合して得られた樹脂5),6) である。比重は 1.03 1.05 , 軟化点 $105 \sim 120^{\circ} \mathrm{C}$ で, 芳香族炭化水素によく溶 ける。その棈造は次のものとされている。<smiles>CC(C)C(O)CCC(C)C(C)(C)C</smiles>

もし, p-t-ブチルフェノールが 粘着剂の本質的な影響を与えるも のであるならば, そのアセチレン の代りに種々の置換基をもつアル デヒドを用いれば，同じ粘着性を 与えるものが得られると想像され る。

Wolf ${ }^{7)}$ らはアルキルフェノールと湓化イオウからア ルキルフェノールサルファイドを合成し, 加硫剤と粘着 剂を兼ね備えたものの製造を試みた。 その構造は次のと㧍りである。

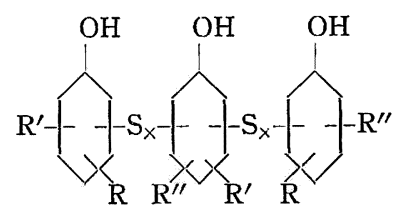

$\mathrm{R}$ と $\mathrm{R}^{\prime}$ は同一かあるいはアルキル基 $\mathrm{R}^{\prime \prime}$ は $\mathrm{H}$ かあるいはアルキル基 $\mathrm{S}_{\times}-\mathrm{S}-,-\mathrm{N}_{\mathrm{S}}-\mathrm{S}-\mathrm{S}$ - など

そして加硫剤と粘着剂としての性質はイオウ含量とアル キル基によって異なり，次のよらな関係をもつ(第1図)。

$\mathrm{p}-\mathrm{t}$-ブチルフェノールサルファイトは SBR に対して 高い粘着性を示す。また一方, 他のアルキルフェノール サルファイトに対しても示す。その $3 \%$ を SBR に分 散した場合に，乾燥時でも高い粘着性を示す。しかしこ れにカーボンブラックを添加すると，たとえ $30 \%$ 程度 加えても低下する。それでも天然ゴムの粘着性にある程 度近づくと述べている。しかしコレシンには及ばない。

Smith ら ${ }^{1)}$ は次の構造で表わされる一連のアルキル フェノール樹脂について粘着剤の試験を行なった。その

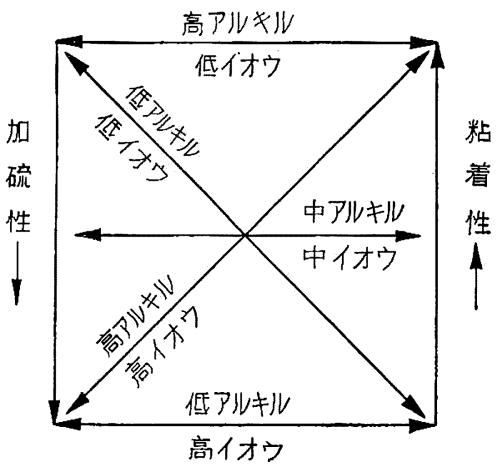

第1図 アルキル基とイオウ含量に対 するアルキルフェノールサル ファイトの加硫性と粘着性

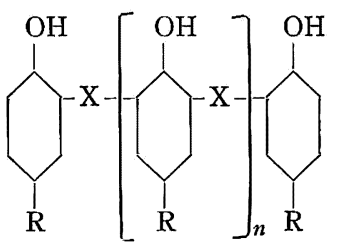

$\mathrm{R} \cdots$ アルルキル, 芳香族ア ラアルキル, アルキ ルは $\mathrm{C}_{1} \sim \mathrm{C}_{6}$ $\mathrm{X} \cdots-\mathrm{S}-, \mathrm{R}^{\prime}-\mathrm{CH}-$,

$\left(\mathrm{R}^{\prime} \mathrm{H}, \mathrm{CH}_{3^{-}}\right)$

結果, $n$ は大きければ大きいほどよく, その $3 \%$ のト ルェン溶液の最小の極限粘度は $\mathrm{X}=-\mathrm{CH}_{2}-0.0835, \mathrm{X}=$ $\mathrm{CH}_{3}-\mathrm{CH} 0.0948, \mathrm{X}=-\mathrm{S}$ と $\mathrm{CH}_{2} 0.0783$ のときが有効 である。特にアルキルフェノール核の間を $-\mathrm{CH}_{2}-$ と -S-で結んだものは同じ極限粘度の $-\mathrm{CH}_{2}-$ に比して高 い粘着性を示すといら。比較的良い例のアルキルフェノ ール樹脂の粘着剤の粘着性と化学構造との関係を第 1 表 第 1 表

\begin{tabular}{|c|c|c|c|c|c|c|}
\hline \multirow{3}{*}{$\begin{array}{l}\text { アルデ } \\
\text { ヒド }\end{array}$} & \multirow{3}{*}{$\begin{array}{l}\text { モル比 } \\
\mathrm{SCl}_{2}\end{array}$} & \multirow{3}{*}{ 軟化点 } & \multicolumn{2}{|c|}{ 粘 } & \multicolumn{2}{|c|}{ 着性 } \\
\hline & & & \multicolumn{2}{|c|}{$\begin{array}{l}\text { ポリマー } \\
\text { 粘着性 }\end{array}$} & \multicolumn{2}{|c|}{$\begin{array}{l}30 \% \text { チャンネ } \\
\text { ルラブック添加 }\end{array}$} \\
\hline & & & 表面 & 加圧 & 表面 & 加圧 \\
\hline HCHO & - & 144 & 3 & 6 & 3 & 7 \\
\hline $\mathrm{CH}_{3} \mathrm{CHO}$ & - & 93 & 3 & 7 & 2 & 6 \\
\hline HCHO & 0.92 & 100 & 4 & 8 & 3 & 6 \\
\hline " & " & 110 & 4 & 9 & 3 & 7 \\
\hline
\end{tabular}

に示す。

この粘着性の評佂法は素練り天然ゴムを 10 とし, それ ぞれの数字は同一種のサンプルを多くの現場技術者によ って手作業で威覚的に集計したもので，ある場合には一 つの作業中, 突然作業者を変更し, 統計的に得たものであ る。なおこのデータはゴム 100 部に対し粘着剤を 10 部 添加し, ロール操作した SBR ゴムを用いたものである。

\section{4. コレシンの化学構造}

SBR の粘着剤の典型であるコレシンは，はたして前 述の構造であるか, Marvel' ${ }^{8)}$ はスペクトル分析から前述 の構造の他に 1,1-ジフェニル 2-フェニルェタンの構造 を認めている。この生成については次のような Meyer 
Schuster 型転位をへて生成したものと考えられる。

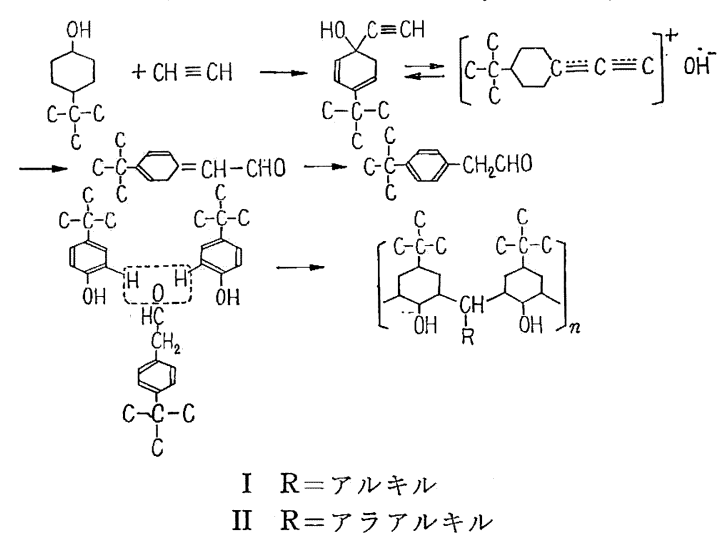

しかし，I はさほど高い粘着性を示さない。II 型をア ルカリ触媒で別の方法で合成したが粘着性がない。もち ろんアルカリ触煤で II を合成しても高い分子量のもの が得られないため高い粘着性を示さないことも考えられ る。フェノールェタン型の樹脂9) は接着凨の粘着を改良 すると述べているので一応考えられるが、コレシンの製 造触媒のナフテン酸西鉛は粘着性を示すので，これらの I, II の構造が混合してコレシンとしての粘着特性を示 すことも一応考えても良い。

\section{Solubility Parameter からみた粘着剂}

接着において，極性が合らか合わないとかを，すなわ ち極性を数字で表わすのに Solubility Parameter（略 して SP) なる理論がある。こ行笹筆者 ${ }^{10) ~ 12) ~ か ゙ し は ゙ し ~}$ ば紹介してきたことである。粘着の物理的な考え方につ いて先に述べたように, ゴムの積層品を重ね, わずかな 圧によって, 両者の接触面が互に流れ, 平坦なるように なるためには梁く接触するか, あるいは接触面において 均一に拡散する必要がある。このためにはゴムと粘着剤 の極性ができるだけ同じものか，あるいはよく近似した ものが必要である。酢酸繊維素 $(\mathrm{SP}=10.9)$ は酢酸エ チル $(\mathrm{SP}=9.1)$ に溶けるが酢酸ブチル $(\mathrm{SP}=8.5)$ に は溶けない。すなわち極性が近似しているものによく溶 ける。同じこの酶酸繊維素はアセトン $(\mathrm{SP}=10)$ にさ らによく溶ける。しかし，酢酸絨維素を溶かさないエ夕
ノール（SP=12.7）を少量このアセトンに添加すると 溶解度がアセトン単独よりもよくなる。換言すれば溶 剂に扔ける $\mathrm{SP}$ 加成性があって, アセトン $(\mathrm{SP}=10)$ とェタノール (12.7) の混合溶骫の SP が酢酸繊維素 (SP=10.9) に近から゙くといらことである。一般に SP の差が 1.5 以上になると溶解性が顕著に低下寸る。 したがって,ゴムなる溶液に粘着剤なる固体を溶かし, 良い分散でゴム組成中に溶解してゆくためには SP が よく合ったものが望をしい。今ここにゴムと粘着鼡 の SP を比較すると第 2 表のとおりである。

筆者はこの見地泣ってキシレン樹脂の粘着剂を提 案した。実際ロール素練りの際に p-t-ブチルフェノ ール型樹脂またはコレシンと同様同量添加したロール操 作では p-t-ブチルフェノール,コレシン型は高い SPを 示すので金属に対する配向性が高く, ロールに粘着して 操作性がむずかしい。しかるにキシレン型は金属に配向 するよりも，SP がゴムに近似しているのでゴムに配向 し, ゴムによく拡散, 溶解してゅく。キシレンは SBR の良い溶剤であるから, そのホルムアルデヒド樹脂のエ ステル変性剂は他の粘着剂に比して, 同じ条件で練り込 んだゴムシートの拡散溶解性は非常に良い。事実ゴムシ 一トを綿密に観察するとある程度肉眼的に見分けがつけ られるものである。しかし, 粘着剤は単に, SBR の加 工性を賦与するだけでなく, 究極的にはゴムに対すを補 強性をもつものが望ましいことはもちろんのことであ る。各種粘着剂を添加した加硫ゴムの性能を第 3 表 ${ }^{13)}$ 示す。

第 3 表からわかるように粘着郕は一般的にみて, 補強 性を示す。しかし，キシレン樹脂は相対的に高い抗張力 と伸び\%を示しているのは高い分散性と若干の反応性を もっているためと考える。

\section{6. むす び}

“必要は発明の母である”という諺があるように，お そらく今後次々と新しいタイプの粘着郕が登場してくる と思う。市販品の中で, 高、疑集力を示す水酸基を含を p-tーブチルフェノール系粘着剤は冷時に损ける压着性が 若干高い反面, 素練り混合分散による深部接触と表面拡

第 2 表 粘着剂の SP とゴムの SP

\begin{tabular}{|c|c|c|c|c|c|c|c|}
\hline 粘 & 着 & 剂 & 種 & 類 & SP & $\exists$ ム の 種 類 & $\mathrm{SP}$ \\
\hline \multirow{2}{*}{\multicolumn{5}{|c|}{$\begin{array}{l}\text { コレシン } \\
\text { p-t-ブチルフェノールホルマリン樹脂 }\end{array}$}} & $11.4 \sim 11.7$ & $\mathrm{SBR}$ スチレン $15 \%$ & 8.45 \\
\hline & & & & & $11.5 \sim 11.8$ & " スチレン $25 \%$ & 8.54 \\
\hline \multicolumn{5}{|c|}{ キシレン樹脂 (エステル型) } & 9.74 & $\mathrm{NBR}:$ ニトリル $25 \%$ & 9.25 \\
\hline " & \multicolumn{4}{|c|}{ (p-t-ブチルフェノール型) } & 10.5 & ネオプレン & 9.38 \\
\hline \multicolumn{5}{|c|}{ クマロン樹脂 } & $6.9 \sim 7.3$ & 天然ゴム & 8.15 \\
\hline \multicolumn{5}{|c|}{ インデン樹脂 } & $7.6 \sim 8.1$ & ポリイソブチレン & 7.7 \\
\hline \multicolumn{5}{|l|}{ 松脂 } & $9.9 \sim 10.5(?)$ & & \\
\hline
\end{tabular}


淡色配合

第 3 表

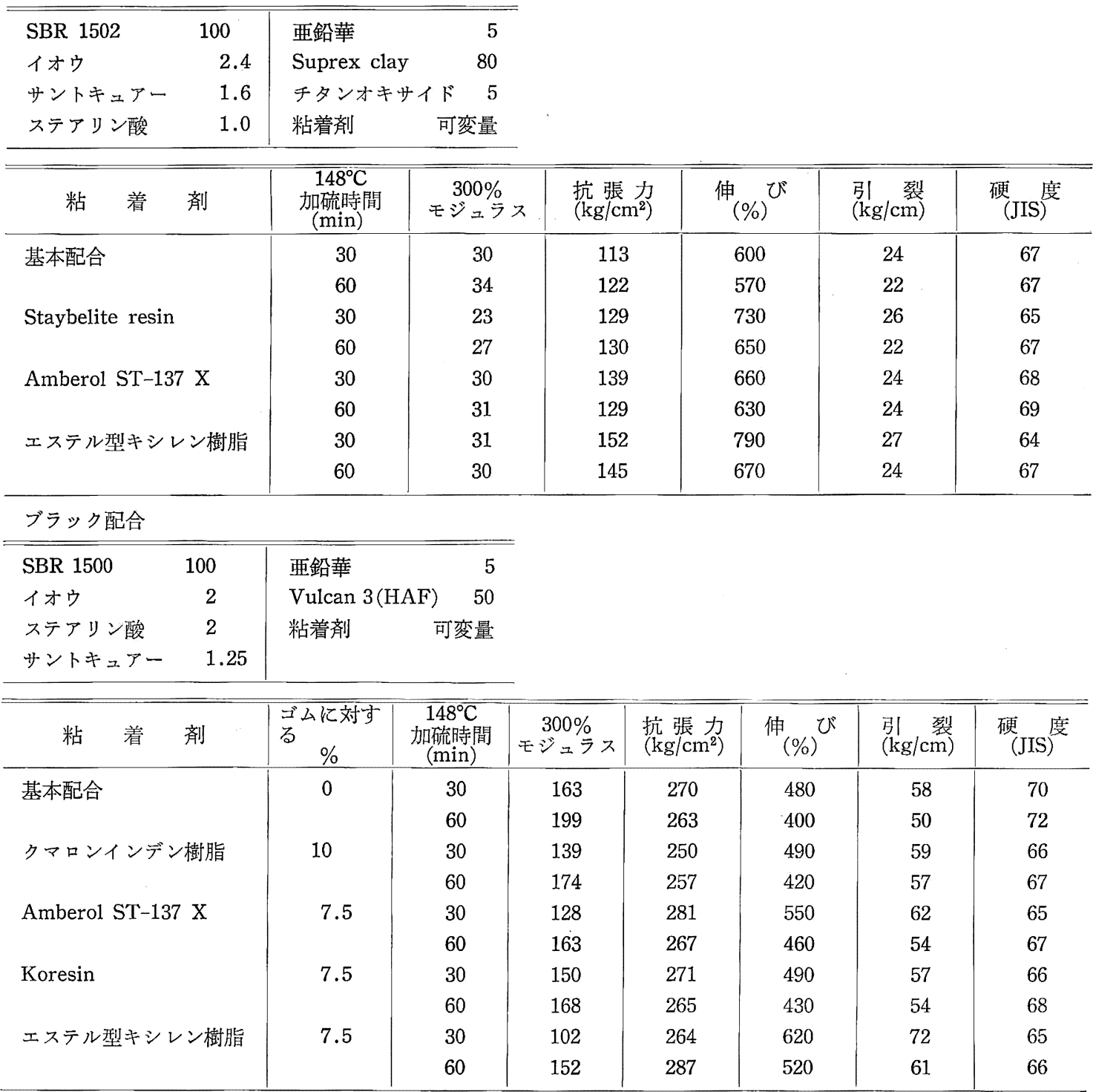

散が低いので, 接触面の全面積にわたる接触性が望みが たい。箨者は p-t-ブチルフェノール系とキシレン系粘 着剤の等量混合物を粘着郕として用いた結果, 両者の長 短を補っているような結果を得た。

$$
\text { 文献 }
$$

1) G. E. P. Smith, J. C. Ambelang and G. W. Goushalk: Ind. Eng. Chem., 38, 1166(1946)

2) Hagen and Harro: Ind. Rubber World, 108, 45 (1943)

3) J. R. Scott: Paint Technol., 9, 218(1944)
4) 箕浦有二: バルカーレビュー, 3, No. 5, 1(1959)

5) J.W.Le Maistre: J.Am. Chem. Soc., 70, 1776(1948)

6) A. O. Zoss: Ind. Eng. Chem., 41, 73(1949)

7) G. M. Wolf, T. E. Deger, H. I. Cramer and C. C. De Hilster: Ind. Eng. Chem., 38, 1157 (1946)

8) C. S. Marvel: J. Polymer Sci., 4, 689(1949)

9) N. J. L. Magson : Chem. \& Ind., 67, 155 (1928)

10) 黄慶雲: 接着, 2 ; 30 (1957)

11) 黄慶雲：プラスチックエージ, 6, No.3, 16(1960)

12) 黄慶雲: 日刊工業新閳, 接着講習会 (昭 35.2.8)

13）今瀬一郎：合成ゴム，1, No. 2, 20 (1959）（日本合 成ゴム KK. 社報） 